\title{
Diversifikasi Produk Tepung Pati Garut (Maranta arundinaceae, Linn.) Menjadi Sohun
}

\author{
Sri Hartati ${ }^{1)}$ dan Sartono Putro ${ }^{2)}$ \\ 1) Fakultas Pertanian, Program Studi Teknologi Hasil Pertanian, Universitas Veteran Bangun Nusantara \\ Sukoharjo. Jl. Letjend S. Humardani No. 1 Kampus Jombor Sukoharjo \\ 2) Jurusan Teknik Mesin Universitas Muhammadiyah Surakarta Kampus Pabelan Surakarta \\ Email: tatik_univet@yahoo.com
}

\begin{abstract}
Abstrak
Berbagai upaya telah dilakukan untuk mengatasi permasalahan terhadap tingginya ketergantungan impor terigu, salah satunya adalah mengembangkan tepung umbi-umbian yang ada di wilayah Nusantara. Diantara umbi potensial adalah garut terutama tepung pati garut. Tujuan penelitian ini adalah diversifikasi tepung pati garut menjadi produk sohun. Umbi garut dibuat tepung pati garut, selanjutnya dibuat sohun. Parameter sohun yang dibuat diuji meliputi penentukan rasio pati dan air untuk gelatinisasi, penentuan rasio pati tergelatinasi dengan pati kering, penentuan cara gelatinasi serta pengujian total cooking loss dan uji sensoris terhadap sohun yang dihasilkan.Pengembangan produk tepung pati garut menjadi sohun menunjukkan bahwa proses pembuatan sohun dengan bahan utama tepung pati garut memerlukan rasio pati dengan air adalah 1:8, rasio pati yang digunakan gelatinasi dan pati kering 1: 11 serta proses pemasakan dengan pengukusan. Sohun yang diproduksi dari tepung pati garut meskipun berbeda dengan sohun komersial namun miliki rasa yang diterima konsumen dan total cooking loss $(6,4249 \%)$ yang memenuhi persyaratan sohun. Tepung pati garut potensial untuk diversifikasi pangan menjadi produk sohun.
\end{abstract}

Kata kunci : diversifikasi, pati garut, sohun, umbi garut

\begin{abstract}
Many efforts have been made to overcome the problem of the high dependence of wheat imports, one of them is to develop tuber flours in Indonesia. Among the potential tuber are Garut (Maranta arundinaceae, Linn.) especially Garut starch. The purpose of this research was to diversify corn starch into vermicelli product. Garut tuber was made to be garut starch, then was made to be vermicelli. The vermicelli parameters that were tested included the determination of starch and water ratio for gelatinization, the gelatinized starch with the dry starch ratio, gelatination determination and the total cooking loss test and the sensory test on the vermicelli produced. The development of Garut starch product into vermicelli showed that the process of making vermicelli with the Garut starch as main ingredient required the ratio of starch to water was 1: 8, the ratio of gelatinized starch and dry starch was 1: 11 and the cooking process by steaming. Vermicelli which was produced from Garut starch flour, although different from commercial vermicelli, but has a sense which can acceptance by consumen and total cooking loss $(6.4249 \%)$ that suitable with the requirements of vermicelli. Garut starch flour was potential for food diversification into vermicelli product.
\end{abstract}

Keywords : diversification, Garut starch, tuber, vermicelli

\section{PENDAHULUAN}

Dampak ketergantungan terhadap
komoditas/produk impor sangat dirasakan masyarakat Indonesia sampai dengan awal tahun 2017. Kenaikan harga sejumlah komoditas seperti kacang kedelai, daging, cabai, bawang putih, bawang merah, dan tepung terigu yang diakibatkan pengaruh resesi ekonomi global dikhawatirkan akan mengarah pada krisis pangan dunia. Badan Pusat Statistik (BPS, 2016) mengumumkan impor barang konsumsi naik 47,68 persen pada Januari 2016, diantaranya karena peningkatan signifikan dari impor gandum untuk bahan baku mie dan roti. Kecenderungan konsumsi tepung dalam negeri terus meningkat. Pada 2016, konsumsi tepung terigu di Indonesia meningkat sebesar $7 \%$ secara yoy (year of year). Tercatat tren pertumbuhan dimulai sejak 2013 dan 
hanya mengalami penurunan $1 \%$ pada 2014 ke 2015 (Aptindo, 2016).

Berbagai upaya telah dilakukan untuk mengatasi permasalahan terhadap tingginya ketergantungan impor terigu, salah satunya adalah mengembangkan tepung umbi-umbian yang ada di wilayah Nusantara. Strategi pengembangan industri pangan melalui pengembangan industri tepung umbi-umbian termasuk tepung garut sebagai tepung alternatif diperlukan dalam upaya mengurangi ketergantungan terigu yang telah mendominasi industri pangan (Anggawisastra, 1992). Salah satu upaya yang dapat dilakukan dalam pengembangan tepung alternatif adalah dengan menggali potensi tanaman lokal antara lain tanaman garut. Hartati dan Sulistyawati (2010) telah melakukan identifikasi potensi dan pendayagunaan sumber pangan lokal untuk penganekaragaman pangan di Kabupaten Sukoharjo. Hasil identifikasi menunjukkan bahwa tanaman garut sangat potensial untuk dikembangkan sebagai bahan penganekaragaman pangan di Sukoharjo. Putro, dkk., (2007) juga telah mengobservasi potensi umbi garut dan menyatakan bahwa salah satu produk yang potensial untuk dikembangkan adalah pembuatan tepung garut dari umbi garut.

Diversifikasi pangan berbasis karbohidrat non beras perlu dikembangkan untuk mendukung ketahanan pangan Indonesia.Salah satu komoditas lokal yang potensial adalah umbi garut.Berbagai olahan umbi garut, tepung garut dan tepung pati garut telah dikembangkan. Umbi garut secara tradisional telah dibuat berbagai olahan pangan seperti garut rebus, criping garut, emping garut, jenang garut dan lain-lain. Tepung garut biasanya digunakan untuk subtitusi pengganti terigu. Tepung pati garut selama ini masih banyak dimanfaatkan untuk keperluan kosmetik dan pengobatan tradisional.

Pati garut, merupakan polimer karbohidrat yang disusun dalam tanaman oleh interaksi antarmolekul protein pembentuk gluten, yaitu dengan ikatan hidrogen dan ikatan disulfida maupun ikatan ionik (Belitz dkk, 1986).Menurut Djaafar dan Rahayu (2006) pati garut dapat dimanfaatkan sebagai bahan substitusi terigu dalam pengolahan pangan. Beberapa penelitian yang dilakukan dengan menggunakan bahan pati garut diantaranya adalah pregelatinasi pati garut sebagai matriks tablet oleh Anwar dkk., (2006). Penelitian substitusi pati garut pada berbagai olahan telah dilakukan diantaranya pada pembuatan mie (Widaningrumdkk.,2001; Widowati dkk., 2002). Wijayanti (2007), melakukan substitusi tepung gandum dengan tepung garut pada pembuatan roti tawar menunjukkan adanya peningkatan kadar serat pangan pada roti tawar sebesar 7,13 - 7,97 \%. Pada penelitian Noor (2008), pembentukan siklodekstrin (pati termodifikasi) dengan hidrolisis pati garut secara enzimatis.Pemanfaatan tepung pati garut menjadi makanan olahan yang memerlukan bahan dengan dominasi tepung garut atau pati garut perlu dilakukan salah satunya dibuat menjadi sohun.

Sohun merupakan produk berbentuk benang atau pita pipih seperti mi terigu, tetapi dibuat dari pati (Haryadi, 2014).Cara-cara pembuatan sohun dari berbagai pati sangat beragam di beberapa wilayah dengan tingkat penerapan teknologi yang beragam, untuk menghasilkan bentuk-bentuk dan ukuran yang beragam, yaitu meliputi bentuk-benrtuk benang lembut, benang besar, pita atau lembaran.Menurut Hormdok dan Noomhorm (2007) tekstur dari sohun masak merupakan sifat kritis yang menentukan penerimaan konsumen. Belum diperoleh informasi formula dan proses pembuatan sohun yang tepat dari bahan tepung pati garut, sehingga penelitian ini diperlukan.Tujuan penelitian secara umum adalah mendapatkan formula dan proses pembuatan sohun dari tepung pati garut. Tujuan secara khusus dalam penelitian ini adalah mengetahui rasio pati dan air untuk gelatinisasi, penentuan rasio pati tergelatinasi 
dengan pati kering, penentuan cara gelatinasi serta pengujian total cooking loss dan uji sensoris terhadap sohun yang dihasilkan.

\section{METODOLOGI PENELITIAN}

\section{Bahan}

Bahan-bahan yang digunakan dalam penelitian ini terdiri dari bahan untuk pembuatan sohun dan pengujiannya.Bahanbahan tersebut terdiri dari tepung pati garut yang dibeli dari produsen pati garut di Kecamatan Polokarto Kabupaten Sukoharjo, air, tepung beras, kertas minyak, dan lain-lain.

Peralatan

Peralatan-peralatan yang digunakan untuk pembuatan dan pengujian sohun antara lain mesin pembuat pasta (Shule pasta machine) panci, bak perendaman, rak-rak penjemur sohun, dan lain-lain.

\section{Jalannya penelitian}

Pembuatan sohun dalam penelitian ini mengadopsi cara yang dilakukan oleh Roisah (2009) dan tergambar seperti tampak pada Gambar 1. Gambar 1 tersebut juga menunjukkan bahwa penelitian ini dilakukan dalam beberapa tahap, meliputi (1) Penentuan rasio tepung pati garut dan air untuk proses gelatinisasi, (2) Penentuan rasio tepung untuk gelatinisasi dan tepung kering/mentah (3)Pemilihanproses pemasakan antara perebusan dan pengukusan terhadap helai adonanpasca pencetakan. (4) Pengujian Total Cooking Loss sohun pati garut serta (5). Uji Sensoris

\section{Penentuan rasio tepung pati garut dan air untuk proses gelatinisasi}

Penentuan rasio tepung pati garut dan air untuk proses gelatinisasi ditujukan untuk menentukan rasio tepung pati garut dan air yang tepat sehingga proses gelatinisasi dalam awal pembuatan sohun telah terbentuk.. Rasio air dan pati garut untuk mendapatkan pati tergelatinasi yang tepat diilakukan dengan beberapa variasi. Variasi tersebut meliputi Gel1 (Rasio pati garut : air = 1:7), Gel-2 ((Rasio pati garut : air $=1: 8$ ) dan Gel-3 (Rasio pati garut : air $=1: 9$ ). Parameter yang digunakan untuk menentukan rasio adalah kepekatan/keenceran adonan dan waktu menjendal (terjadi gelatinisasi) saat dipanaskan. Penjendalan ditentukan secara visual dengan terjadinya perubahan warna dan kepekatan adonan. Setelah diperoleh rasio yang tepat, dilanjutkan tahap selanjutnya untuk memperoleh proporsi yang tepat antara tepung pati untuk gelatinasi awal dengan tepung pati garut kering yang ditambahkan untuk membentuk adonan.

\section{Penentuan rasio tepung untuk gelatinisasi dan tepung kering/mentah}

Penentuan rasio tepung pati untuk gelatinasi awal dengan tepung pati kering ditujukan untuk memperoleh sifat adonan pati yang sesuai sehingga pencetakan dan pemasakan sohun tidak mengalami hambatan dengan demikian mutu akhir sohun menjadi seperti yang diharapkan. Setelah rasio tepung pati garut dan air untuk proses gelatinisasidiperoleh rasio yang tepat, dilanjutkan orientasi untuk memperoleh proporsi yang tepat antara pati tergelatinasi dengan penambahan tepung pati garut kering meliputi beberapa variasi yaitu GP.1 $=(1: 9)$, GP.2 = (1:10), GP.3= (1:11) dan GP.4 = (1:12) Parameter yang digunakan untuk menentukan rasio yang tepat adalah sifat adonan (lengket, kalis, dan sangat kalis) dan kemudahan adonan untuk dicetak.. Pengamatan dilakukan secara visual dan subyektif.Setelah diperoleh adonan yang berbentuk bola, yang lunak dan tidak lengketadonan (kalis) dilanjutkan dengan orientasi proses pemasakan meliputi perebusan atau pengukusan.

Pemilihan proses pemasakan antara perebusan dan pengukusan terhadap helai adonan pasca pencetakan.

Pemilihan proses pemasakan helai adonan pasca pencetakan ditujukan untuk 
memilih proses pemasakan yang tepat sehingga diperoleh helai sohun mirip tali dan teruraidan tidak lengket. Setelah diperoleh bola adonan pati yang lunak dan tidak lengk et di tangan (adonan kalis) selanjutnya adonan diekstrusi menggunakan ektruder. Setelah lolos dari ekstruder adonan dibagi 2 bagian, bagian satu masuk ke panci perebusan pada air mendidih, dan satu bagian masuk pada panci pengukus yang juga airnya telah mendidih. Masing-masing mengalami perebusan atau pengukusan selama 5 menit. Pengamatan dilakukan setelah helai adonan keluar dari masing-masing proses pemasakan. Proses pemasakan yang menghasilkan helai adonan sohun yang mirip tali dan terurai serta tidak lengket yang dipilih. Setelah diperoleh proses yang sesuai dilakukan produksi sohun dengan cara proses terpilih. Sohun diuji meliputi cooking loss, daya regang serta uji sensoris.

\section{Pengujian Total Cooking Loss sohun pati garut}

Pengujian Total Cooking Loss terhadap sohun yang dibuat menggunakan prosedur analisa Total Cooking Loss menurut Mestres et al, 1998 dalam Haryadi, 2014. Air $(150 \mathrm{ml})$ dipanaskan di bawah reflux dalam gelas beker $250 \mathrm{ml}$. Saat air mendidih, dimasukkan sohun 5 $\mathrm{g}$ yang telah dipotong-potong sepanjang $2 \mathrm{~cm}$. Lama pemasakan optimum ditentukan dengan pengujian penekanan menggunakan sepasang plat kaca. Pemasakan dilanjutkan selama 1 menit setelah lama pemasakan optimum.Sampel selanjutnya ditiriskan selama 5 menit dan segera ditimbang (W1, g).Produk matang selanjutnya dikenai pengeringan pendahuluan dalam oven IR dan dikeringkan dalam oven pada suhu $130^{\circ} \mathrm{C}$, sampai tercapai berat konstan (W2, g).Air perebus disentrifus (7500 x g) selama 10 menit. Selanjutnya, kadar bahan kering dalam endapan dan supernatan (W3, g dan W4, g) ditentukan dengan cara menguapkan air endapan dan supernatan. Total cooking loss meliputi bahan padat dan bahan terlarut yang hilang, yang dihitung menggunakan persamaan berikut (DM = rasio bahan kering dalam sampel awal)

Total cooking loss $(\mathrm{TCL} ; \%)=(5 \times \mathrm{DM}-$ W2) $\times 100 /(5 \times \mathrm{DM})$

\section{Uji Sensoris}

Uji sensoris dilakukan menggunakan uji pembedaan duo-trio dengan jumlah panelis agak terlatih 20 orang. Sebagai pembanding (kontrol) adalah sohun yang beredar di pasaran dengan merk Pandawa yang diproduksi di Desa Manjung Kecamatan Ngawen Kabupaten Klaten dengan bahan baku pati aren. Panelis diminta memberikan tanda angka 1 untuk sampel yang berbedadengan kontrol $(K)$ dan angka 0 untuk yang samadengan kontrol $(K)$. Jumlah panelis yang merespon dibandingkan dengan Tabel Duo-trio untuk memperoleh jumlah terkecil untuk menyatakan beda nyata sampel yang diuji.

\section{HASIL DAN PEMBAHASAN}

Pengembangan produk tepung pati garut yang potensial salah satunya adalah dengan dibuat menjadi produk sohun karena dalam pembuatan sohun kebutuhan bahan dasar pati adalah dominan.Sohun merupakan produk berbentuk benang atau pita pipih seperti mi terigu, tetapi dibuat dari pati (Haryadi, 2014). Cara-cara pembuatan sohun dari berbagai pati sangat beragam di beberapa wilayah dengan tingkat penerapan teknologi yang beragam, untuk menghasilkan bentuk-bentuk dan ukuran yang beragam, yaitu meliputi bentuk-benrtuk benang lembut, benang besar, pita atau lembaran.

Proses Pembuatan sohun tepung pati garut yang dilakukan dalam penelitian ini mengacu pada proses pembuatan sohun dari tepung pati ganyong seperti yang dilakukan oleh Roisah (2009). Untuk mengetahui apakah proses pembuatan sohun dari tepung pati ganyong sesuai untuk tepung pati garut, 
diperlukan beberapa orientasi dengan tujuan (1) mendapatkan rasio tepung pati garut dan air untuk proses gelatinisasi (2) mendapatkan rasio tepung untuk gelatinisasi dan tepung kering serta (3) mendapatkan proses pemasakan yang tepat.

\section{Penentuan rasio tepung pati garut dan air untuk proses gelatinisasi.}

Penentuan rasio tepung pati garut dan air untuk proses gelatinisasi dalam proses pembuatan sohun sangat penting dilakukan. Hasil penelitian seperti tersaji dalam Tabel 1 (Lampiran) memperlihatkan bahwa rasio untuk proses gelatinisasi yang paling sesuai adalah tepung pati garut : air $=1: 8$.

Kadar air akhir memiliki pengaruh yang sangat nyata pada sifat-sifat fisik sohun. Kadar air dalam adonan pati juga menunjukkan jumlah total pati, sehingga berpengaruh pada mutu akhir sohun (Haryadi, 2014).

Setelah diperoleh rasio yang tepat, dilanjutkan orientasi untuk memperoleh proporsi yang tepat antara pati tergelatinasi dengan penambahan tepung pati garut kering meliputi beberapa variasi yaitu GP1, GP2, GP3 dan GP4. Setelah diperoleh adonan yang kalis dilanjutkan dengan orientasi proses pemasakan meliputi perebusan atau pengukusan. Setelah diperoleh proses yang sesuai dilakukan produksi sohun dengan cara proses terpilih. Sohun diuji meliputi cooking loss dan uji sensoris.

\section{Penentuan rasio tepung untuk gelatinisasi dan tepung kering/mentah}

Penentuan rasio tepung untuk gelatinisasi dan tepung pati kering penting dilakukan untuk memperoleh sifat adonan pati yang sesuai sehingga pencetakan dan pemasakan sohun tidak mengalami hambatan dengan demikian mutu akhir sohun menjadi seperti yang diharapkan. Rasio tepung untuk keperluan gelatinisasi dengan tepung kering sehingga kadar air adonan pati menjadi sekitar
$50 \%$ dalam penelitian ini tampak seperti pada Tabel 2 (Lampiran).

Tabel 2 memperlihatkan bahwa rasio terpilih antara tepung untuk gelatinisasi dan tepung kering adalah 1:11 untuk membentuk adonan yang siap cetak. Haryadi (2014) menyatakan bahwa beberapa laporan tentang bahan yang berbeda bervariasi dalam proporsi antara pati mentah : pati tergelatinasi, $1: 1 \mathrm{s.d}$ $1: 3$ (b/b) dan kadar air antara 45-60\%. Rasio yang lebih rendah atau lebih tinggi dari pati tergelatinasi menghasilkan slurry yang terlalu kering atau terlalu lunak untuk diekstrusi.

\section{Pemilihan proses pemasakan antara perebusan dan pengukusan terhadap helai adonan pasca pencetakan}

Setelah diperoleh bola adonan pati yang lunak dan yag tidak lengket di tangan (adonan kalis) selanjutnya adonan diekstrusi menggunakan ektruder. Setelah lolos dari ekstruder adonan dibagi 2 bagian, bagian satu masuk ke panci perebusan pada air mendidih, dan satu bagian masuk pada panci pengukus yang juga airnya telah mendidih. Masingmasing mengalami perebusan atau pengukusan selama 5 menit. Proses gelatinasi penuh dapat dilakukan baik dengan perebusan maupun pengukusan (Haryadi, 2014). Hasil sohun sebagaimana tampak pada Tabel 3 (Lampiran).

Tabel 3 menunjukkan bahwa dalam pembuatan sohun dari tepung pati garut proses pemasakan yang sesuai adalah dengan pengukusan. Pengukusan merupakan proses pemberian panas pada suatu bahan dengan memanfaatkan uap air panas. Dalam proses pengukusan ini mengakibatkan pada tergelatinasinya pati garut namun tidak mematahkan helai-helai sohun yang tercetak. Sementara ada proses perebusan karena terjadi perendaman dengan air panas maka mengalami kesulitan saat pengambilan kembali 
Hartati \& Putro, 2017

sehingga helaian sohun sebagian patah/hancur.

\section{Pengujian Total Cooking Loss sohun pati garut}

Konsumen umumnya menyukai sohun kering yang bersih, transparan dan tampak mengkilat, sedang warna putih keruh kurang disukai.Kualitas sohun banyak ditentukan oleh sifat-sifat sohun masaknya yang meliputi sifat susut berat kering karena pemasakan (total cooking loss), daya regang putus (tensile strength) serta ketahanan terhadap pemotongan (cutting stress). Sifat susut berat karena pemasakan menunjukkan banyaknya kehilangan berat kering sohun akibat sebagian komponen pati bahan baku sohun mengalami pelarutan selama proses pemasakan. Nilai susut berat karena pemasakan berpengaruh pada sifat pengunyahan, apabila nilainya besar maka sohun akan terasa lembek.

Hasil pengukuran terhadap total cooking loss sohun pati garut dalam penelitian ini yang dibandingkan dengan sohun komersial (Gambar 2) menunjukkan bahwa terdapat perbedaan yang nyata antara sohun pati garut dan sohun komersial (bahan utama pati aren). Hal ini dikarenakan perbedaan jenis pati berpengaruh terhadap atribut mutu total cooking loss.

Gambar 2 (Lampiran) memperlihatkan bahwa sohun pati garut memiliki Total cooking loss lebih besar dibanding sohun komersial, namun masih dalam kategori yang diterima. Susut berat akibat pemasakan (Total cooking loss) merupakan selisih berat kering sohun sebelum dimasak dengan berat kering sohun setelah dimasak.Cooking loss merupakan jumlah substansi padatan yang hilang bersama air saat pemasakan berdasarkan hasil dari pemasakan mie (Kurniawan dkk., 2015). Menurut Lii dan Chang (1990) susut berat kering sohun yang baik tidak boleh lebih dari $10 \%$.

\section{Sensoris}

Sifat sensoris didefinisikan sebagai tingkat penerimaan atribut sensoris oleh konsumen yang merupakan pengguna biasa dari kategori produk (Galves dan Resurrection, 1992).Uji sensoris dilakukan menggunakan uji pembedaan duo-trio dengan jumlah panelis agak terlatih 20 orang. Sebagai pembanding (kontrol) adalah sohun yang beredar di pasaran dengan merk Pandawa yang diproduksi di Desa Manjung Kecamatan Ngawen Kabupaten Klaten dengan bahan baku pati aren. Hasil analisis sebagai tampak pada Tabel 4 (Lampiran).

Dari Tabel uji Duo-trio jumlah terkecil untuk menyatakan beda nyata pada uji Duo-trio dengan hipotesis berekor dua diperoleh angka bahwa untuk jumlah panelis 20 orang jumlah terkecil untuk beda nyata tingkat $5 \%$ adalah 15 , tingkat $1 \% \quad 17$ dan tingkat $0,1 \%$ adalah 17 . Dengan demikian sohun dari tepung pati garut dari segi warna, tekstur dan rasa sangat berbeda dengan sohun dari tepung pati aren, sedang pada kesukaan sohun dari para panelis menunjukkan hampir sama.

\section{KESIMPULAN}

Pengembangan produk tepung pati garut menjadi sohun menunjukkan bahwa proses pembuatan sohun dengan bahan utama tepung pati garut memerlukan rasio pati dengan air adalah $1: 8$, rasio pati yang digunakan gelatinasi dan pati kering 1: 11 serta proses pemasakan dengan pengukusan. Sohun yang diproduksi dari tepung pati garut meskipun berbeda dengan sohun komersial namun miliki rasa yang diterima konsumen dan total cooking loss $(6,4249 \%)$ yang memenuhi persyaratan sohun. 
Tabel 1. Rasio tepung pati garut dan air untuk proses gelatinisasi

\begin{tabular}{|c|c|c|c|c|}
\hline \multicolumn{2}{|c|}{ Rasio } & \multirow{2}{*}{$\begin{array}{l}\text { Nama } \\
\text { sampel }\end{array}$} & \multirow{2}{*}{$\begin{array}{c}\text { Waktu mengalami } \\
\text { Gelatinisasi (menjendal) }{ }^{\star} \text { ) }\end{array}$} & \multirow{2}{*}{ sifat gelatinisasi } \\
\hline Tepung & air & & & \\
\hline 1 & 7 & Gel -1 & $3,18 \pm 0,34$ menit & $\begin{array}{c}\text { pekat sehingga terlalu cepat } \\
\text { tergelatinisasi }\end{array}$ \\
\hline 1 & 8 & Gel-2 & $5,02 \pm 0,52$ menit & tepat/sesuai \\
\hline 1 & 9 & Gel-3 & $10,23 \pm 0,43$ menit & $\begin{array}{c}\text { encer sehingga lama proses } \\
\text { tergelatinisasi }\end{array}$ \\
\hline
\end{tabular}

Keterangan : ${ }^{*}$ ) rerata 3 kali ulangan

Tabel 2. Rasio tepung untuk gelatinisasi dan tepung kering

\begin{tabular}{|c|c|c|c|c|}
\hline \multicolumn{2}{|c|}{ Rasio } & \multirow[b]{2}{*}{$\begin{array}{l}\text { Nama } \\
\text { Sampel }\end{array}$} & \multirow[b]{2}{*}{ sifat adonan } & \multirow[b]{2}{*}{ Hasil pencetakan } \\
\hline Tepung & $\begin{array}{l}\text { tepung } \\
\text { kering }\end{array}$ & & & \\
\hline 1 & 9 & GP.1 & Lengket dan becek & Tidak bisa dicetak \\
\hline 1 & 10 & GP.2 & Lengket dan becek & Tidak bisa dicetak \\
\hline 1 & 11 & GP.3 & kalis & $\begin{array}{c}\text { Dicetak dapat membentuk } \\
\text { helai sohun }\end{array}$ \\
\hline 1 & 12 & GP.4 & Sangat kalis & $\begin{array}{l}\text { Dicetak helai sohun patah- } \\
\text { patah }\end{array}$ \\
\hline
\end{tabular}


Pati : air

Gel-1 ( 1:7), Gel-2 ( 1:8) dan Gel-3 (1:9)

\section{Gelatinisasi (suhu $61-75^{\circ} \mathrm{C}$}

Rasio pati yang digunakan untuk gelatinisasi : pati kering GP.1 (1:9), GP.2 (1:10), GP.3(1:11) dan GP.4 (1:12)

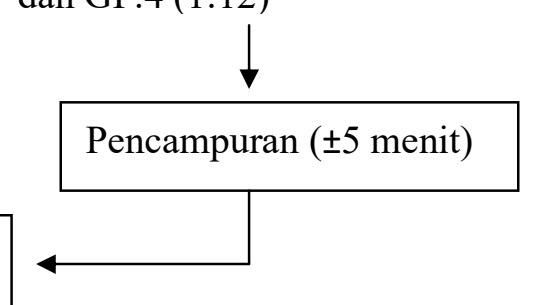

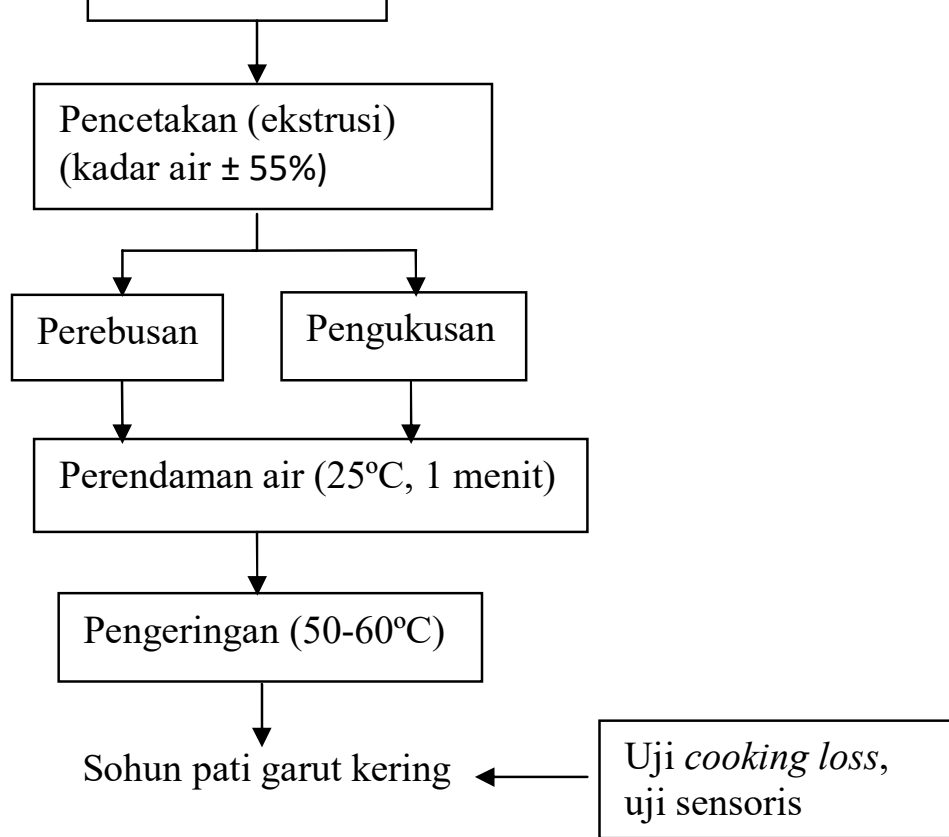

Gambar 1. Diagram alir pembuatan sohun tepung pati garut

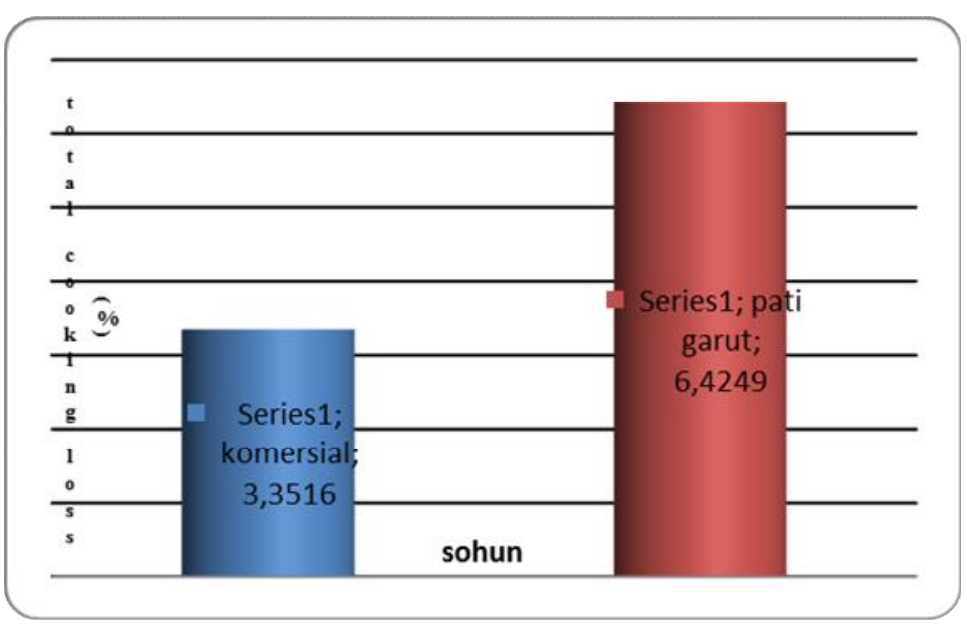


Gambar 2. Total cooking loss sohun pati garut dibandingkan sohun komersial (pati aren)

Tabel 3. Hasil proses pemasakan sohun antara perebusan dan pengukusan

\begin{tabular}{|c|c|}
\hline Perebusan & Pengukusan \\
\hline Helai sohun saling melekat dan patah & Helai sohun mirip tali dan terurai \\
\hline & \\
& \\
\hline
\end{tabular}

Tabel 4. Hasil uji sensoris dengan metode duo-trio sohun dari tepung pati garut

\begin{tabular}{lcc}
\hline Atribut yang dinilai & $\begin{array}{l}\text { Jumlah panelis } \\
\text { merespon } \\
\text { beda dengan kontrol }\end{array}$ & $\begin{array}{l}\text { Jumlah panelis merespon } \\
\text { sama dengan control }\end{array}$ \\
\hline Warna & 17 & 3 \\
/kenampakan & 18 & 2 \\
tekstur & 18 & 2 \\
rasa & 8 & 12 \\
Kesukaan (overall) & & \\
\hline
\end{tabular}

\section{DAFTAR PUSTAKA}

Anggawisastra, K. 1992. Strategi Pengembangan Industri Pangan dan Gizi pada Pelita VI. Informasi Pangan dan Gizi. Direktorat Gizi Masyarakat. Depkes RI III (3). 23h.

Anwar, E., Yusmarlina, D., Rahmat, H., dan Kosasih, 2006. Fosforilasi pregelatinasi pati garut (Marantaarundinaceae L.) sebagai matriks tablet lepas terkendali teofilin. Majalah Farmasi Indonesia, 17(1), 37 -44 .

Aptindo (Asosiasi Tepung Produsen Tepung Terigu Indonesia), 2016. Konsumsi Tepung Terigu Nasional Melambat.15
Desember 2016..'http://ads.bisnis.com.
Belitz, H.D., R. Kieffer, W. Seilmeier, and H.Weiser. 1986. Structure and function of gluten protein. Cereal Chemistry 63(4):336-341.

Djaafar, T.F. dan S. Rahayu. 2006. Teknologi Pemanfaatan Umbi Garut, Pangan Sumber Karbohidrat. Badan Ketahanan Pangan bekerjasama dengan Pusat Kajian Makanan Tradisional Universitas Gadjah Mada, Yogyakarta.

Galves, F. C. F. dan Resurrection, A. V. A., 1992. Reliability of the Focus Group 
Tahun 2007. Litbang BAPPEDA Kabupaten Sukoharjo.

Quantity Characteristics of Mung Bean (Vigna radiata (L.) Wilezec) noodles. Journal of Sensory Studies. 7:315-326.

Haryadi, 2014. Teknologi Mi, Bihun, Sohun. Gadjah Mada University Press. Yogyakarta.

Hartati,S \& Sulistyawati, 2010. Identifikasi Potensi dan Pendayagunaan Sumber Pangan Lokal untuk Penganekaragaman Pangan di Kabupaten Sukoharjo Jawa Tengah. Widyatama No.1/Nol.19/2010 Hal : 30-36.

Hoormdok, R., and Noomhorm, A., 2007. Hydrothermal treatment of rice starch for improvement of rice noodle quality. LWT-Food Science and Technology, 40, 1723-1731.

Kurniawan, A., Estiasih, T., Nur Ida Panca Nugrahini, N. I. P.,Mie Dari Umbi Garut (Maranta arundinacea L.): Kajian Pustaka Noodles from arrowroot (Maranta arundinacea L.): A Review. Jurnal Pangan dan Agroindustri Vol. 3 (3):847-854.

Lii, C. Y., dan Chang, S.M., 1990. Characterization of Red Bean (Phaseolus Radiatus var. Aurea) Starch and Its Noodle Quality. Journal of Food Science. 46: 78-81.

Noor, E., 2008. Hidrolisis Pati Garut Secara Enzimatis untuk Pembentukan Siklo dekstrin. Jurnal Imu Pertanian Indonesia, Vol.13 (2) : 90-94.

Putro, S, Hartati S, Musabbikhah, 2007. Inventarisasi Kreativitas dan Inovasi Masyarakat Kabupaten Sukoharjo
Roisah, 2009. Produksi Dan Karakterisasi Sohun Dari Pati Ganyong (Canna edulis Ker). Skripsi Fakultas Teknologi Pertanian Institut Pertanian Bogor. Bogor.

Rahmawati, Norhikmah dan Komari, 2002. Pengaruh Subtitusi Parsial Tepung Terigu dengan Tepung Pati Garut dan Penambahan Gliseril Monostearat (GSM) terhadap Mutu Roti Tawar. Abstrak. Seminar Nasional PATPI, Malang. Hal. 28.

Riduwan, 2003, Skala Pengukuran Variablevariabel Penelitian, IKAPI: Jakarta.

Rukmana Rahmat. 2000. Garut :Proses dan Penanganan Pasca Panen. Penerbit Kanisius, Yogyakarta.

Sukarminah E, Mohamad Djali dan Omadi, 2002. Pengaruh Imbangan Pati Garut (Maranta Arundinaceae, Linn) dengan Tepung Kacang Hijau terhadap Karakteristik Cookies. Abstrak. Seminar Nasional PATPI, Malang. Hal. 143.

Suryani Lilis,C., 2001. Karakterisasi Amilografi Pati Ganyong Putih, Ubi Jalar dan Garut serta Sifat-sifat Fisik Sohun yang Dihasilkan. Himpunan Makalah Seminar Nasional Teknologi Pangan. PATPI Semarang.

Whistler R L, James N Bemiller and Eugene F Paschall, 1984.Starch :Chemistry and Technology. Academic Press Inc. Harcourt Brace Jovanovich, Publisher Orlando-San Diego-New York.

Widaningrum, Widowati, S., Soewarno T. Soekarto, 2001, Garut Pengganti 
Agrisaintifika

Jurnal Ilmu-Ilmu Pertanian

Vol. 1, No. 1, 2017

Hartati \& Putro, 2017

Gandum dan Beras, Berkhasiat Obat, Departemen Kesehatan Gizi.

Widowati S, B A S Santosa dan Widaningrum, 2002. Studi Pengolahan Mie dengan Subtitusi Tepung Garut dan Kedelai. Prosiding Seminar Nasional PATPI, Malang. Hal. 117.
Wijayanti, Y.R., 2007. Substitusi Tepung Gandum (Triticum Aestivum) denganTepung Garut (Maranta Arundinaceae L) pada Pembuatan Roti Tawar. Skripsi. Jurusan Teknologi Pangan Dan Hasil Pertanian, Fakultas Teknologi Pertanian, Universitas Gadjah Mada, Yogyakarta. 